\title{
Solution-Processed Titanium Oxide for Rear Contact Improvement in Heterojunction Solar Cells
}

\author{
Yu-Tsu Lee ${ }^{1}$, Fang-Ru Lin ${ }^{1}$ and Zingway Pei ${ }^{1,2,3, * \mathbb{D}}$ \\ 1 Department of Electrical Engineering, National Chung Hsing University, Taichung 40227, Taiwan; \\ bill90867@hotmail.com (Y.-T.L.); ginkgo0518@hotmail.com (F.-R.L.) \\ 2 Graduate Institute of Optoelectronic Engineering, National Chung Hsing University, Taichung 40227, Taiwan \\ 3 Innovation and Development Center of Sustainable Agriculture, National Chung Hsing University, \\ Taichung 40227, Taiwan \\ * Correspondence: Zingway@dragon.nchu.edu.tw; Tel.: +886-4-2258-1549
}

Received: 7 August 2020; Accepted: 3 September 2020; Published: 7 September 2020

\begin{abstract}
In this work, we demonstrated a heterojunction Si solar cell utilizing chemically grown titanium oxide $\left(\mathrm{TiO}_{\mathrm{x}}\right)$ as an electron-selective contact layer at its rear surface. With $\mathrm{TiO}_{\mathrm{x}}$, the rear surface was passivated to reduce carrier recombination. The reverse saturation current, which is an indicator of carrier recombination, exhibited a 4.4-fold reduction after placing a $\mathrm{TiO}_{\mathrm{x}}$ layer on the rear surface. With reduced recombination, the open-circuit voltage increased from $433 \mathrm{mV}$ to $600 \mathrm{mV}$ and consequently, the power conversion efficiency (PCE) increased from 9.57 to $14.70 \%$. By X-ray photoemission spectroscopy, the surface passivation was attributed to a silicon oxide interfacial layer formed during the chemical growth process. This passivation results in a $625 \mathrm{~cm} / \mathrm{s}$ surface recombination velocity for the $\mathrm{TiO}_{x}$-passivated $\mathrm{Si}$ surface, which is 2.4 times lower than the sample without $\mathrm{TiO}_{\mathrm{x}}$, ensuring the carriers pass through the rear contact without extensive recombination. According to these results, the band alignment for the heterojunction solar cell with and without a $\mathrm{TiO}_{\mathrm{x}}$ rear contact layer was plotted, the reduced interfacial recombination and the electron and hole blocking structure are the main reasons for the observed efficiency enhancement.
\end{abstract}

Keywords: titanium oxide; electron-selective; chemical grown; surface passivation; heterojunction solar cell

PACS: J0101

\section{Introduction}

With appropriate band alignment to $\mathrm{Si}$, the sub-stoichiometric transition metal oxides (TMOs) [1], such as titanium oxide $\left(\mathrm{TiO}_{\mathrm{x}}\right)$ [2-4], molybdenum oxide $\left(\mathrm{MoO}_{\mathrm{x}}\right)$ [5], and nickel oxide $\left(\mathrm{NiO}_{\mathrm{x}}\right)$ [6], have been investigated as either an electron-selective or a hole-selective contact in silicon solar cells. Conventionally, the ohmic contacts in Si were fabricated by depositing metals on a heavily-doped region, which is expensive and complex for Si solar cells. These TMO materials, generally deposited by either liquid phase deposition, thermal evaporation, or magnetron sputtering, exhibiting Ohmic contact in low resistance by appropriate band alignment, involve low temperature and low-cost processes. For example, a thin $\mathrm{MoO}_{\mathrm{x}}$ film could be used to replace the boron-doped a-Si:H in a SHJ solar cell to achieve $22.5 \%$ PCE by improving short-circuit current density $\left(J_{s c}\right)$ [7]. Due to its high valence-band energy, a $\mathrm{TiO}_{\mathrm{x}}$ film demonstrated a large valence-band offset $(\sim 2.0 \mathrm{eV})$ to silicon forming a hole-blocking interface [8]. At the same time, the conduction band energy of $\mathrm{TiO}_{\mathrm{x}}$ is similar to the $\mathrm{Si}$, enabling electrons to pass through with effect-less barrier, as an electron-selective contact. Therefore, by using a $\mathrm{TiO}_{\mathrm{x}}$ hole blocking contact, a silicon solar cell that exhibits a PCE of $11.2 \%$ could 
be obtained [9]. However, those studies generally focus on the ability of replacing the front layer by an electron-selective $\mathrm{TiO}_{\mathrm{x}}$ one, but rarely on the rear contact properties. Furthermore, in addition to electron-selectivity, the ability of interface passivation is also important to obtain high open-circuit voltages and high fill factors in a silicon solar cell. In this work, we utilize a full-area electron-selective $\mathrm{TiO}_{\mathrm{x}}$ layer grown by liquid phase deposition (LPD) as a rear contact of Si to achieve high-efficiency. LPD is a fully chemical growth process, allowing the $\mathrm{TiO}_{x}$ layer to be grown uniformly. The ability for rear surface passivation was studied by examining the reverse saturation current, which is an indicator of carrier recombination in a junction diode. The advantage of rear surface passivation was explored by the external quantum efficiency at long wavelength. The origin of passivation was observed by X-ray photoemission spectroscopy and attributed to the formation of silicon oxide at the Si surface. The small surface recombination velocity that was calculated by minority carrier lifetime, ensures the carriers pass through the contact without extensive recombination.

\section{Experimental Procedures}

To fabricate the proposed solar cell, an n-type, $175 \mu \mathrm{m}$ thick surface polished crystalline (100) silicon wafer $(0.5-1 \Omega-\mathrm{cm})$ was used as substrate. Prior to deposition, the Si substrate was textured in a potassium hydroxide $(\mathrm{KOH})$ solution and etched in an etchant solution $\left(\mathrm{HF}: \mathrm{H}_{2} \mathrm{O}=1: 10\right)$ for $30 \mathrm{sec}$ to remove surface damage and then rinsed with deionized water. After cleaning, a thin layer of intrinsic a-Si:H ( $5 \mathrm{~nm})$ and B-doped a-Si:H $(20 \mathrm{~nm})$ are deposited sequentially by plasma-enhanced chemical vapor deposition (13.56 MHz). A $80 \mathrm{~nm}$ thick indium-tin oxide (ITO) transparent conductor was then deposited by sputtering. After that, the front surface was passivated with photoresist for rear-side $\mathrm{TiO}_{\mathrm{x}}$ deposition. The $\mathrm{TiO}_{\mathrm{x}}$ was deposited in 8,16 , and $25 \mathrm{~nm}$ thicknesses by a LPD method, details of which were published previously [2,3]. $\left(\mathrm{NH}_{4}\right)_{2} \mathrm{TiF}_{6}$ solution and $\mathrm{H}_{3} \mathrm{BO}_{3}$ were used as precursors. To ensure a saturated concentration of $\mathrm{TiO}_{\mathrm{x}}, \mathrm{TiO}_{\mathrm{x}}$ powders were added to the precursor. The deposition temperature was maintained at $40{ }^{\circ} \mathrm{C}$. The concentrations of $\left(\mathrm{NH}_{4}\right)_{2} \mathrm{TiF}_{6}$ and $\mathrm{H}_{3} \mathrm{BO}_{3}$ were $0.2 \mathrm{M}$ and 0.6 $\mathrm{M}$, respectively, in deionized water. The growth of $\mathrm{TiO}_{2}$ consists of two equilibrium reactions. In the first step, the TiF ligand interacts with $\mathrm{H}_{2} \mathrm{O}$ to form a titanium hydroxyl complex and $\mathrm{HF}$ (Equation (1)). The titanium hydroxyl complex is further transformed into $\mathrm{TiO}_{\mathrm{x}}$ through a dehydration reaction. To maintain the continuous growth of $\mathrm{TiO}_{x}$, the first equation should work forward by reducing the concentration of $\mathrm{F}$ ion simultaneously. This was achieved by the reaction of $\mathrm{H}_{3} \mathrm{BO}_{3}$ with $\mathrm{HF}$ in the second step (Equation (2)) [10,11]:

$$
\begin{gathered}
{\left[\mathrm{TiF}_{6}\right]^{2-}+n \mathrm{H}_{2} \mathrm{O} \leftrightarrow\left[\mathrm{TiF}_{6-n}(\mathrm{OH})_{n}\right]^{2-}+n \mathrm{HF}} \\
\mathrm{H}_{3} \mathrm{BO}_{3}+4 \mathrm{HF} \leftrightarrow \mathrm{HBF}_{4}+3 \mathrm{H}_{2} \mathrm{O}
\end{gathered}
$$

In this step, the chemical reaction consumes uncoordinated $\mathrm{F}$ to form stable $\mathrm{BF}_{4}{ }^{-}$ions. Therefore, the consumption of the HF drives the chemical reaction represented in the Equation (1) toward $\mathrm{TiO}_{x}$ deposition on the substrate by dissolving supersaturated $\mathrm{TiO}_{2}$ powder in the solution, in order to balance the chemical reaction. After $\mathrm{TiO}_{x}$ deposition, the photoresist was removed. The front $(\mathrm{Ag} \sim 100 \mathrm{~nm})$ and back contact $(\mathrm{Al} \sim 200 \mathrm{~nm})$ were deposited sequentially by a thermal evaporator through a shadow mask. The schematic diagram of the resulting solar cell device is shown in Figure 1a. To analyse the device, the dark current density voltage (I-V) characteristics were measured by a B2912A semiconductor parameter analyzer (Agilent, Santa Clara, CA, USA) on a probe station. The photovoltaic characteristics were measured by a calibrated solar simulator under AM1.5 G $\left(100 \mathrm{~mW} / \mathrm{cm}^{2}\right)$ conditions. A QE-3000 system (Titan Electro-Optics, Taipei, Taiwan) was used to obtain external quantum efficiency (EQE). To study the material properties, a transmission electron microscope (TEM, model JEM-2100F, JEOL, Tokyo, Japan) was used to explore the $\mathrm{TiO}_{\mathrm{x}} / \mathrm{Si}$ interfaces. X-ray Photoelectron Spectroscopy (XPS, model PHI 5000 Versa Probe, ULVAC-PHI, Kanagawa, Japan) was used to understand the microstructure of $\mathrm{TiO}_{x}$ on Si. The lifetime was measured by a WCT-120 system (Sinton, Boulder, 
CO, USA) in quasi-steady-state photoconductance mode. The surface recombination velocity was calculated from the obtained lifetime.

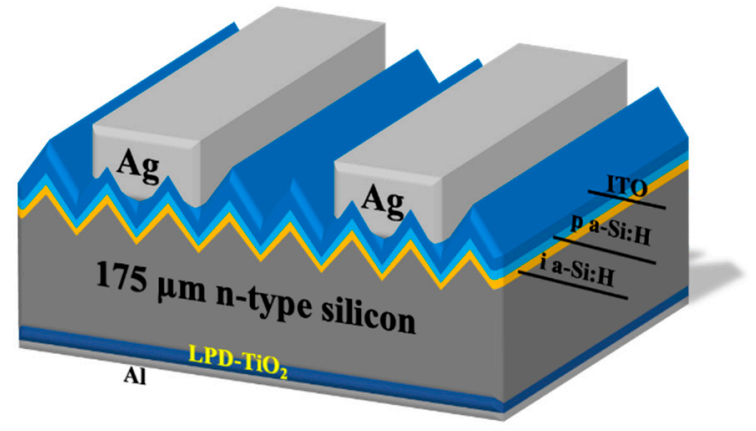

(a)

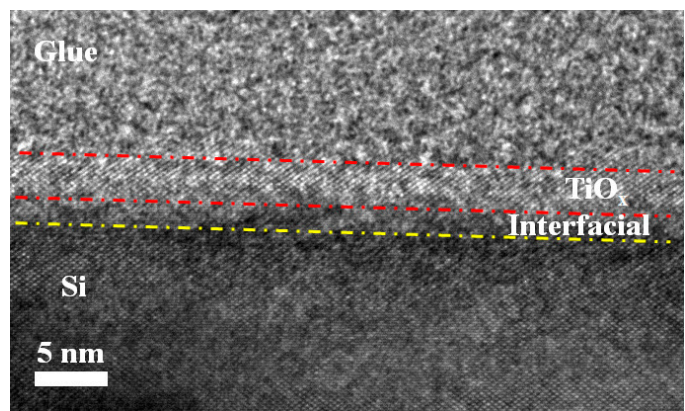

(b)

Figure 1. (a)The schematic diagram of the fabricated heterojunction solar cell that exhibits an LPDgrown interfacial layer between $\mathrm{Al}$ and $\mathrm{Si}$ at its rear surface. (b) TEM images of thin $\mathrm{TiO}_{\mathrm{x}}$ layer on the Si surface. The sample $\mathrm{TiO}_{\mathrm{x}}$ layer was grown uniformly on the Si surface.

\section{Results and Discussions}

A TEM image of the $\mathrm{TiO}_{x} / \mathrm{Si}$ interface is shown in Figure $1 \mathrm{~b}$. To grow a thin $\mathrm{TiO}_{\mathrm{x}}$ layer, the growth rate is the key factor in the LPD process. The growth rate was determined by the thickness measurement on a thicker $\mathrm{TiO}_{\mathrm{x}}$ by SEM. The $\mathrm{TiO}_{\mathrm{x}}$ was then grown to the designed thickness by controlling the time in the LPD process. In Figure $1 b$, the designed thickness is $5 \mathrm{~nm}$. From the figure, the interfacial and $\mathrm{TiO}_{\mathrm{x}}$ layers are approximately 1 and $4 \mathrm{~nm}$ thick, as indicated. The measured thickness is consistent with the designed thickness, therefore, the thickness used in the device indicates matches the design thickness. The dark and photo-current density to voltage characteristics (J-V) are illustrated in Figure 2a,c, respectively. Without solar light illumination, both solar cell devices with and without a $\mathrm{TiO}_{x}$ rear contact layer exhibit normal pn-junction diode behavior. The solar cell without $\mathrm{TiO}_{\mathrm{x}}$ rear contact layer exhibits a higher current density for the same applied voltage. This implies the carriers are injected into device much easier without a $\mathrm{TiO}_{\mathrm{x}}$ rear contact layer, however, the ease of injection also indicates the possibility of a smaller open-circuit voltage $\left(V_{o c}\right)$, in which the $V_{o c}$ is determined as the voltage at which the solar generation current and the injected current are balanced. The ideality factor, $\mathrm{n}$, of both devices was calculated and is shown in Figure $2 \mathrm{~b}$ by the following pn-junction diode equations, as shown in Equation (3):

$$
J=J_{0}\left(\exp \left(\frac{q V}{n k T}\right)-1\right)
$$

in which $J$ is the diode current, $J_{0}$ is the reverse saturation current density, $q$ is the electric charge of electron, $\mathrm{k}$ is the Boltzman constant, $T$ is the absolute temperature, $V$ is the applied voltage and the $n$ is the ideality factor. The term $n$ generally accounts for recombination at either the bulk or junctions, the heterointerfaces, and contact resistance under forward-biased conditions [12]. The calculated ideality factor for a solar cell without a $\mathrm{TiO}_{\mathrm{x}}$ rear contact layer is approximately 1.73 at a voltage smaller than $0.45 \mathrm{~V}$ and it increases rapidly after $0.45 \mathrm{~V}$. In comparison, the solar cell with a $8 \mathrm{~nm}$ thick $\mathrm{TiO}_{\mathrm{x}}$ rear contact layer exhibits a higher ideality factor, approximately 2.3 , at voltages smaller than $0.55 \mathrm{~V}$ and a slight increase after this voltage. Since the bulk and the front contacts are identical for both solar cells, the difference in ideality factor must be caused by the rear contact, either from rear interface recombination or due to the interfacial barrier provided by $\mathrm{TiO}_{\mathrm{x}}$. The rapidly increased ideality factor at voltages higher than $0.45 \mathrm{~V}$ indicates a high voltage-drop in this region that may be attributed to high interfacial states for recombination in solar cells without a $\mathrm{TiO}_{\mathrm{x}}$ rear contact layer. This could be clarified by the reverse saturation current, $J_{0}$, under reversed biased conditions, in which the $J_{0}$ contains information of the generation and recombination processes in the entire device. The reverse saturation current density, $J_{0}$, for a reference device (without $\mathrm{TiO}_{x}$ ) is $1.1 \times 10^{-7} \mathrm{~A} / \mathrm{cm}^{2}$, and it is $2.5 \times 10^{-8} \mathrm{~A} / \mathrm{cm}^{2}$ 
for a device with a $\mathrm{TiO}_{x}$ rear contact layer. The solar cell device with $\mathrm{TiO}_{x}$ exhibits approximately a 4.4-fold reduction. These findings indicate that insertion of a thin layer of $\mathrm{TiO}_{\mathrm{x}}$ may passivate the density of states of $\mathrm{Si}$ on the rear surface and improve the electrical contact behavior.

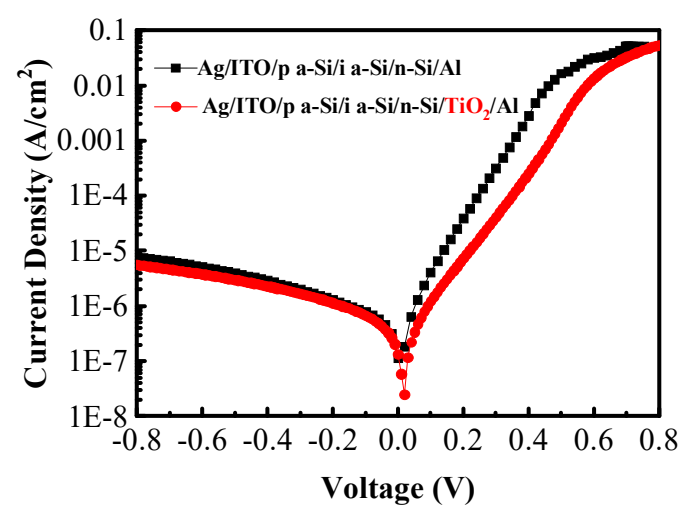

(a)

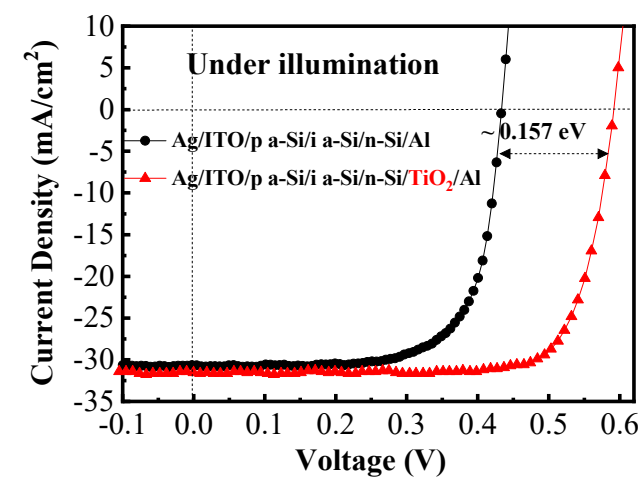

(c)

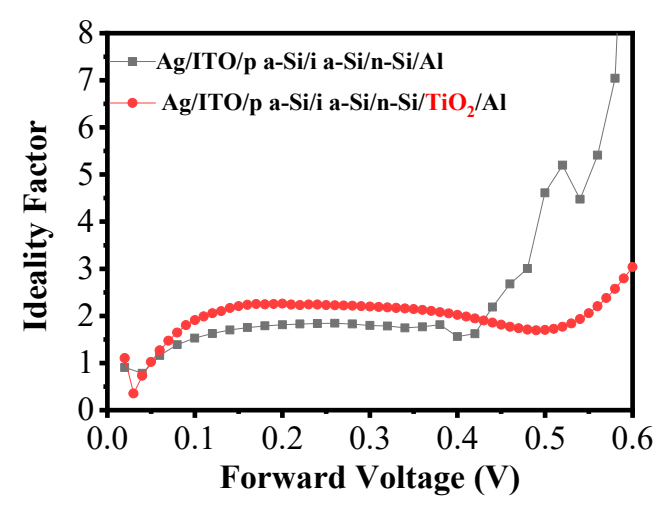

(b)

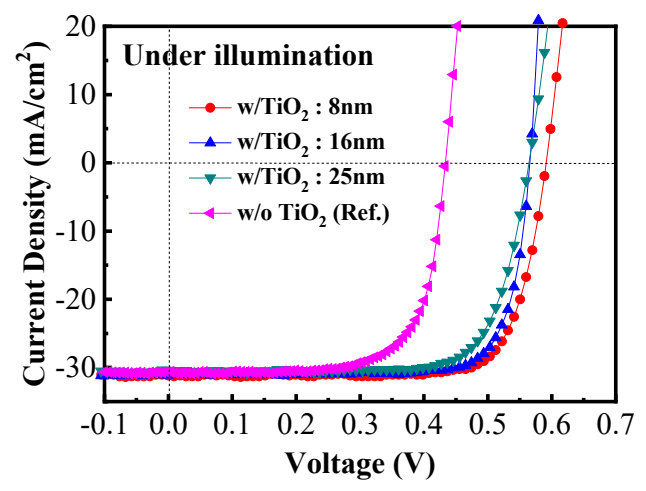

(d)

Figure 2. (a)The diode current density-voltage characteristics for the solar cell without and with $8 \mathrm{~nm}$ thick $\mathrm{TiO}_{\mathrm{x}}$ rear contact layer at dark environment. (b) The ideality factor that calculated from the diode characteristics. (c) The diode current density-voltage characteristics for the solar cell without and with $8 \mathrm{~nm}$ thick $\mathrm{TiO}_{\mathrm{x}}$ rear contact layer under solar simulator illumination. (d) The diode current density-voltage characteristics for the solar cell without and with a $\mathrm{TiO}_{\mathrm{x}}$ rear contact layer of different thickness under solar simulator illumination.

The photocurrent-voltage characteristics of the $\mathrm{TiO}_{\mathrm{x}}$ and referenced solar cells are illustrated in Figure 2c. The short-circuit current density $\left(J_{s c}\right)$, fill factor $(\mathrm{FF})$ and open-circuit voltage $\left(V_{o c}\right)$ of a solar cell with an $8 \mathrm{~nm} \mathrm{TiO}$ rear interfacial layer are $31.5 \mathrm{~mA} / \mathrm{cm}^{2}, 0.778$, and $0.6 \mathrm{~V}$, respectively. As a consequence, a power conversion efficiency (PCE) of $14.70 \%$ is achieved. Without a $\mathrm{TiO}_{\mathrm{x}}$ rear contact, the values of those solar cell performance indicators are $30.7 \mathrm{~mA} / \mathrm{cm}^{2}, 0.716$, and $0.43 \mathrm{~V}$, yielding an PCE of $9.57 \%$. With the increased thickness of $\mathrm{TiO}_{x}(16$ and $25 \mathrm{~nm})$, the $V_{o c}$ of devices decreased slightly, as compared to the solar cell device with a $8 \mathrm{~nm}$ thick $\mathrm{TiO}_{\mathrm{x}}$ rear contact layer. The PCE was reduced slightly to 13.81 and $12.96 \%$, respectively. The details of the $V_{o c}, J_{s c}, \mathrm{FF}, \mathrm{PCE}$, series resistance (Rs) and shunt resistance (Rsh) for the solar cell devices are listed in Table 1. 
Table 1. Photovoltaic characteristics of the $\mathrm{TiO}_{\mathrm{x}} / \mathrm{Si}$ heterojunction SOLAR CELLS.

\begin{tabular}{|c|c|c|c|c|c|c|}
\hline Parameter & $V_{o c}(\mathrm{mV})$ & $J_{s c}\left(\mathrm{~mA} / \mathrm{cm}^{2}\right)$ & Fill Factor & PCE $(\%)^{b}$ & $\operatorname{Rs}\left(\Omega-\mathrm{cm}^{2}\right)$ & $\operatorname{Rsh}\left(\Omega-\mathrm{cm}^{2}\right)$ \\
\hline Ref. $^{a}$ & 433 & 30.7 & 0.716 & 9.57 & 2.59 & 1562 \\
\hline $8 \mathrm{~nm}$ & 600 & 31.5 & 0.778 & 14.70 & 2.46 & 1244 \\
\hline $16 \mathrm{~nm}$ & 566 & 30.9 & 0.790 & 13.81 & 1.89 & 1564 \\
\hline $25 \mathrm{~nm}$ & 564 & 30.4 & 0.756 & 12.96 & 3.67 & 776 \\
\hline
\end{tabular}

The enhancement in the $V_{o c}$ for the $\mathrm{TiO}_{\mathrm{x}}$ device is consistent with the higher ideality factor at forward-biased and the low recombination current density under reverse-biased conditions given by the following expression:

$$
V_{o c}=\frac{n k T}{q} \ln \left(\frac{J_{s c}}{J_{0}}+1\right)
$$

According to this equation, a high ideality factor and low recombination current density will result in a high $V_{o c}$ if the photocurrent density remains constant. In contrast to $V_{o c}$, the $J_{s c}$ is similar for devices with and without $\mathrm{TiO}_{\mathrm{x}}$. They show only a slight difference, which is $0.7 \mathrm{~mA} / \mathrm{cm}^{2}$. The EQE for these two devices was taken at wavelengths from 400 to $1200 \mathrm{~nm}$ to understand the origin of the $J_{s c}$ enhancement, as shown in Figure 3. The EQE for both devices are almost identical before $800 \mathrm{~nm}$. After this wavelength, the device with $\mathrm{TiO}_{\mathrm{x}}$ shows a slight enhancement. The enhancement ratio was calculated and is displayed in the lower part of Figure 3. The enhancement is increased around 20\% at wavelengths near $1100 \mathrm{~nm}$. Usually long wavelength incident light can reach the rear side of a Si solar cell because of the low absorption coefficient at these wavelengths. Therefore, the enhancement in the EQE is attributed to the formation of $\mathrm{TiO}_{x}$ at the rear contact that passivates the interfaces. The microstructure of the $\mathrm{TiO}_{\mathrm{x}}$ and $\mathrm{Si}$ interface will be discussed later using an XPS investigation. In addition to the interface passivation, the valence band edge of the $\mathrm{TiO}_{\mathrm{x}}$ samples are higher than the edge of the valence band of the $\mathrm{Si}$ from our previous study, as the $\mathrm{TiO}_{\mathrm{x}}$ will repel photogenerated holes back to the front contact, which increases the $J_{s c}$ and EQE.

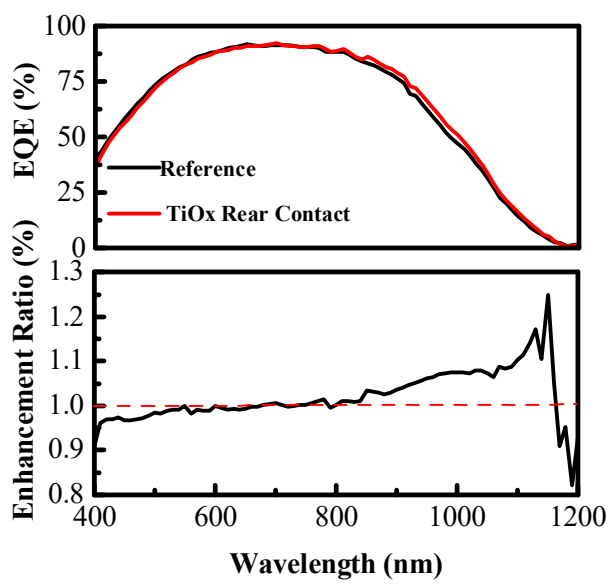

Figure 3. The external quantum efficiency (EQE) for the solar cells with and without a $\mathrm{TiO}_{\mathrm{x}}$ rear contact layer at wavelengths ranging from 400 to $1200 \mathrm{~nm}$ (upper). Enhancement of EQE for the solar cells with and without $\mathrm{TiO}_{\mathrm{x}}$ rear contact layer calculated from the EQE spectrum (lower).

Figure 4a depicts the $\mathrm{O}_{1 \mathrm{~s}}$ and $\mathrm{Si}_{2 \mathrm{p}}$ core-level microstructure of the $\mathrm{TiO}_{\mathrm{x}}$ obtained according to the XPS results. The $\mathrm{O}_{1 \mathrm{~s}}$ spectrum exhibits three peaks after deconvolution, which correspond to $\mathrm{TiO}_{2}(530.7 \mathrm{eV})$, oxygen deficient $\mathrm{TiO}_{x}(531.4 \mathrm{eV})$ and $\mathrm{SiO}_{\mathrm{x}}(532.5 \mathrm{eV})$ [13-15]. The Si-bonded O signal covers a broad energy range, that overlapps with the oxygen-deficient $\mathrm{TiO}_{\mathrm{x}}$ signal, indicating the existence of oxygen deficient $\mathrm{SiO}_{x}$ and cross-bonding, such as $\mathrm{Si}-\mathrm{O}-\mathrm{Ti}$. The $\mathrm{Si} 2 \mathrm{p}$ signal has two peaks, corresponding to $\mathrm{Si}(99 \mathrm{eV})$ and $\mathrm{Si}-\mathrm{O}(102 \mathrm{eV})$, respectively [16]. The appearance of Si-O bonding 
reveals a small amounts of silicon oxide exists either in the $\mathrm{TiO}_{\mathrm{x}}$ or at the $\mathrm{Si}$ surface. The formation of $\mathrm{SiO}_{\mathrm{x}}$ is a natural result in the LPD process. Water will react with the Si surface to form the oxide naturally. The HF will further dissolve $\mathrm{SiO}_{2}$ into solution by etching. Finally, the dissolved $\mathrm{SiO}_{2}$ and $\mathrm{TiO}_{2}$ will regrow on the native oxide to form a layer comprising $\mathrm{SiO}_{x}, \mathrm{TiO}_{x}$ and $\mathrm{TiO}_{2}$.
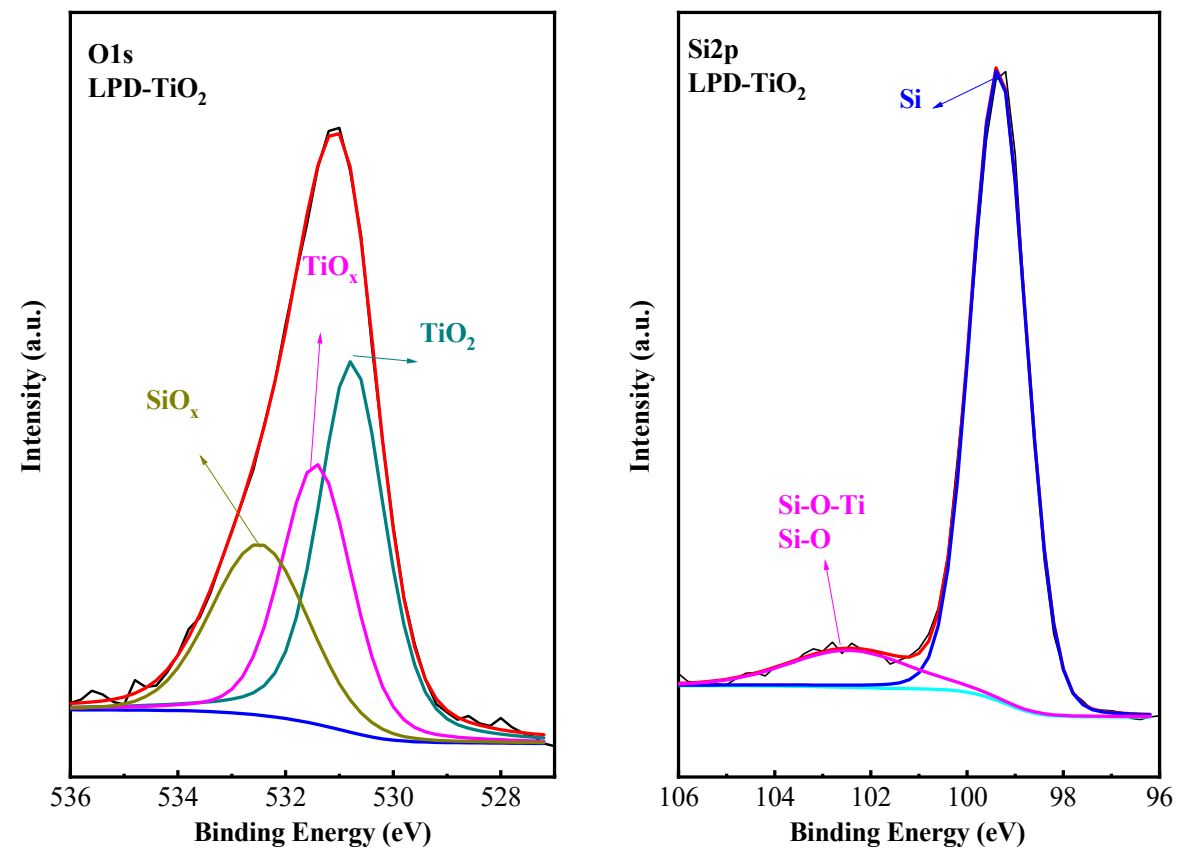

(a)

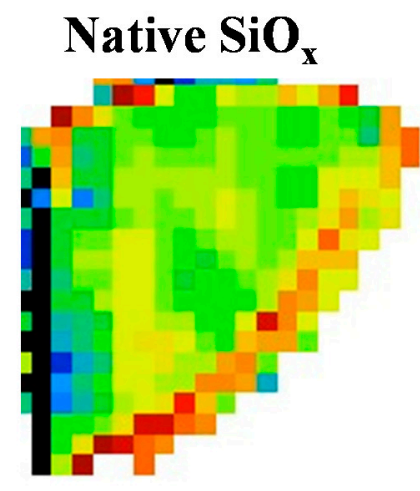

${\mathrm{LPD}-\mathrm{TiO}_{2}}$

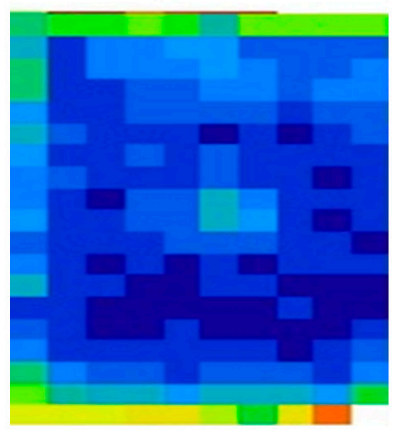

\section{$11 \mu \mathrm{s}$}

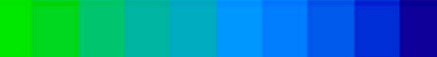

$45 \mu \mathrm{s}$

(b)

Figure 4. (a) The $\mathrm{O}_{1 \mathrm{~s}}$ and $\mathrm{Si}_{2 \mathrm{p}}$ core-level microstructure of the $\mathrm{TiO}_{\mathrm{x}} / \mathrm{Si}$ obtained by XPS. (b) The images of the minority carrier lifetime for Si surfaces without (covered by native oxide) and with $\mathrm{TiO}_{\mathrm{x}}$ passivation.

The reduction in the dark current density provides evidence of improved junction quality. The formation of the $\mathrm{SiO}_{\mathrm{x}}$ between $\mathrm{Si}$ and $\mathrm{TiO}_{\mathrm{x}}$ could passivate the interfaces reducing the recombination. The physical evidence is the reduction of the surface recombination velocity (S). The SRV could be 
derived by the minority carrier lifetime $(\tau)$. The relationship of $S$ and $\tau$ could be expressed by the following equation $[17,18]$ :

$$
\frac{1}{\tau}=\frac{1}{\tau_{b}}+\frac{2 S}{W}
$$

in which the $\tau$ is the minority carrier lifetime by measurement, $\tau_{b}$ is the averaged bulk lifetime, $S$ is the surface recombination velocity to be calculated, and $\mathrm{W}$ is the wafer thickness. The minority carrier lifetime for the bare-Si (with native oxide) and $\mathrm{TiO}_{x}$-grown $\mathrm{Si}$ are indicated at Figure $4 \mathrm{~b}$. The bare-Si and $\mathrm{TiO}_{\mathrm{x}}$-grown $\mathrm{Si}$ had average lifetimes of 16.8 and $40 \mu \mathrm{s}$, respectively. To calculate the $\mathrm{S}$, the bulk lifetime was assumed to be $19 \mathrm{~ms}$ [19]. The $\mathrm{S}$ values were 625 and $1488 \mathrm{~cm} / \mathrm{s}$ for $\mathrm{TiO}_{\mathrm{x}}$ and native oxide grown $\mathrm{Si}$ surface, respectively, by calculation. The $\mathrm{TiO}_{\mathrm{x}}$ exhibits a 2.4-fold reduction of the surface recombination velocity compared to native oxide on $\mathrm{Si}$. As a consequence, the $\mathrm{TiO}_{\mathrm{x}} / \mathrm{Si}$ has better passivation ability than native oxide.

The band alignments of the proposed device structure are plotted at Figure $5 \mathrm{a}, \mathrm{b}$ for the heterojunction $(\mathrm{HJ})$ solar cell with and without a $\mathrm{TiO}_{\mathrm{x}}$ rear contact layer, respectively. The conduction band edge $\left(E_{C}\right)$ and valence band edge $\left(E_{V}\right)$, for the $\mathrm{Si}(100)$ are $4.01 \mathrm{eV}$ and $5.17 \mathrm{eV}$ below the vacuum level, respectively. The Fermi energy $\left(\mathrm{E}_{\mathrm{F}}\right)$ of the $\mathrm{n}$-type $\mathrm{Si}$ is calculated according to the doping concentration (resistivity $\sim 0.5 \Omega-\mathrm{cm}$ ), which is $4.22 \mathrm{eV}$. The titanium oxide with empty and filled band edges at $4 \mathrm{eV}$ and $7.2 \mathrm{eV}$ below the vacuum level, respectively. Furthermore, the Fermi energy of the $\mathrm{LPD}^{-\mathrm{TiO}_{\mathrm{x}}}$ layer is $4.2 \mathrm{eV}$ [3]. The conduction band and valence edges are $3.9 \sim 4.0$ and $5.6 \sim 5.7 \mathrm{eV}$ for amorphous silicon (a-Si:H) adopted from literature [20,21]. The band gap of a-Si:H is assumed to be $\sim 1.7 \mathrm{eV}$ [22]. With heavy B-doping, the a-Si:H film has a work function of $4.9 \mathrm{eV}$.

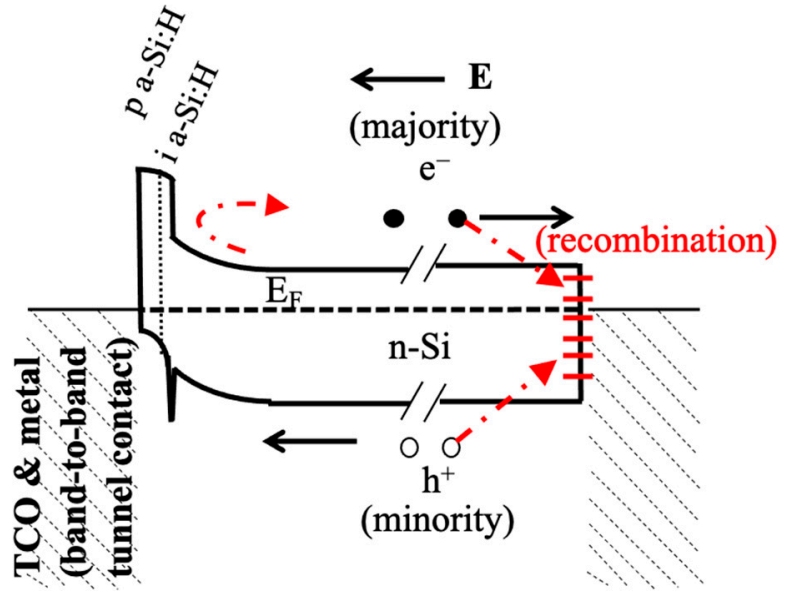

(a)

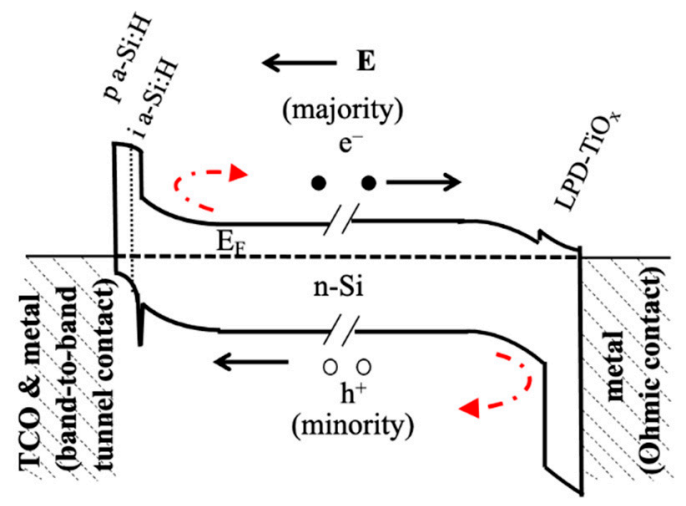

(b)

Figure 5. The schematic band alignment for the Si heterojunction solar cell (a) without and (b) with a chemically grown $\mathrm{TiO}_{x}$ rear contact layer. The electron- and hole- blocking were plotted.

In both device structures, the B-doped a-Si:H film can be used as an electron blocking layer to push electrons moving from the anode to the cathode preventing electron recombination at the p-type doping region. Meanwhile, the holes could be collected by the anode despite a "spike" barrier. However, the alignment is quite different for the rear contact. The grown of a thin $\mathrm{TiO}_{\mathrm{x}}$ layer between $\mathrm{Si}$ and the contact metal offers two advantages. One is the building of a hole blocking layer that prevents holes from recombining at the cathode side. The other contribution is the passivation of defects at $\mathrm{Si} / \mathrm{Al}$ interfaces. One suggestion is the formation of $\mathrm{AlO}_{\mathrm{x}}$ at interfaces [23]. The $\mathrm{Al}$ atoms have a large oxygen affinity that easily attracts oxygen atoms from the $\mathrm{TiO}_{\mathrm{x}}$ interlayer to form an interfacial $\mathrm{AlO}_{\mathrm{x}}$ layer by a redox reaction after annealing. This interfacial $\mathrm{AlO}_{\mathrm{x}}$ layer is assumed to be a nonstoichiometric Al-rich layer that accounts for the low contact resistivity obtained for these devices. However, this cannot be clarified in our structure, as $\mathrm{Al} / \mathrm{TiO}$ interfaces cannot be studied 
because the thin $\mathrm{TiO}_{\mathrm{x}}$ layer is grown underneath a thick $\mathrm{Al}$ layer. On the other hand, the growth of titanium oxide on the Si surface by a liquid phase method with oxygen-containing precursors also induces the growth of oxide at interfaces. The composition of the $\mathrm{TiO}_{2}$ layer is highly oxygen-deficient $\mathrm{TiO}_{2-x}$ and contains a $\mathrm{SiO}_{\mathrm{x}}$ interfacial layer in our experiments. The high oxygen deficiency reveals that $\mathrm{LPD} \mathrm{TiO}_{x}$ exhibits high conductivity due to the free electron generation by oxygen vacancies [6]. Therefore, the contact resistivity at the $\mathrm{Si} / \mathrm{TiO}_{\mathrm{x}}$ interface is small due to the higher conductivity and hence the cell's FF improves [7]. The formation of the interfacial Si oxide will passivate the Si surface, as understood from the $\mathrm{X}$-ray photoemission spectroscopy results.

\section{Conclusions}

In conclusion, we have demonstrated a metal-oxide/Si heterojunction solar cell utilizing a low temperature liquid phase process-grown titanium oxide layer. With a rear interface engineering $\mathrm{TiO}_{\mathrm{x}}$ layer, a power conversion efficiency of $14.70 \%$ is achieved, a $9.57 \%$ enhancement. The reduction of carrier recombination at the rear surface causes this enhancement by improving the open-circuit voltage from 433 to $600 \mathrm{mV}$. The formation of interfacial Si oxide and the increased minority carrier lifetime from 16.8 to $40 \mathrm{~ms}$, imply the interface between $\mathrm{Al}$ and $\mathrm{Si}$ was well-passivated. In addition, the formation of $\mathrm{TiO}_{\mathrm{x}}$ at the rear surface also cause a hole-blocking behavior that enhances the short-circuit current and partially reduces the recombination. As a consequence, chemically grown titanium oxide is suitable for application in high performance, low cost Si solar cells.

Author Contributions: Y.-T.L. and Z.P. designed the experiments; F.-R.L. performed the experiments; Y.-T.L. and Z.P. analyzed the data; Y.-T.L. and Z.P. wrote the paper. All authors have read and agreed to the published version of the manuscript.

Funding: This research was funded by Ministry of Science and Technology of (MOST) Taiwan under grant MOST 108-2221-E-005-061-, MOST 108-2638-E-005-001-MY2, MOST 109-2218-E-005-012- and Ministry of Education, Taiwan, R.O.C. under Higher Education Sprout Project. And the APC was founded by MOST 108-2638-E-005001-MY2.

Conflicts of Interest: The authors declare no conflict of interest.

\section{References}

1. Meyer, J.; Hamwi, S.; Kröger, M.; Kowalsky, W.; Riedl, T.; Kahn, A. Transition Metal Oxides for Organic Electronics: Energetics, Device Physics and Applications. Adv. Mater. 2012, 24, 5408-5427. [CrossRef]

2. Lee, Y.-T.; Lin, F.-R.; Chen, C.-H.; Pei, Z. A 14.7\% Organic/Silicon Nanoholes Hybrid Solar Cell via Interfacial Engineering by Solution-Processed Inorganic Conformal Layer. ACS Appl. Mater. Interfaces 2016, 8, 34537-34545. [CrossRef]

3. Lee, Y.-T.; Lin, F.-R.; Lin, T.-C.; Chen, C.-H.; Pei, Z. Low-Temperature, Chemically Grown Titanium Oxide Thin Films with a High Hole Tunneling Rate for Si Solar Cells. Energies 2016, 9, 402. [CrossRef]

4. Lee, C.; Bae, S.; Park, H.; Choi, D.; Song, H.; Lee, H.; Ohshita, Y.; Kim, D.; Kang, Y.; Lee, H.-S. Properties of Thermally Evaporated Titanium Dioxide as an Electron-Selective Contact for Silicon Solar Cells. Energies 2020, 13, 678. [CrossRef]

5. Battaglia, C.; Yin, X.; Zheng, M.; Sharp, I.D.; Chen, T.; McDonnell, S.; Azcatl, A.; Carraro, C.; Ma, B.; Maboudian, R.; et al. Hole Selective MoOx Contact for Silicon Solar Cells. Nano Lett. 2014, 14, 967-971. [CrossRef]

6. Islam, R.; Shine, G.; Saraswat, K.C. Schottky barrier height reduction for holes by Fermi level depinning using metal/nickel oxide/silicon contacts. Appl. Phys. Lett. 2014, 105, 182103. [CrossRef]

7. Geissbühler, J.; Werner, J.; Martin de Nicolas, S.; Barraud, L.; Hessler-Wyser, A.; Despeisse, M.; Nicolay, S.; Tomasi, A.; Niesen, B.; De Wolf, S.; et al. 22.5\% efficient silicon heterojunction solar cell with molybdenum oxide hole collector. Appl. Phys. Lett. 2015, 107, 081601. [CrossRef]

8. Avasthi, S.; McClain, W.E.; Man, G.; Kahn, A.; Schwartz, J.; Sturm, J.C. Hole-blocking titanium-oxide/silicon heterojunction and its application to photovoltaics. Appl. Phys. Lett. 2013, 102, 203901. [CrossRef] 
9. Nagamatsu, K.A.; Avasthi, S.; Sahasrabudhe, G.; Man, G.; Jhaveri, J.; Berg, A.H.; Schwartz, J.; Kahn, A.; Wagner, S.; Sturm, J.C. Titanium dioxide/silicon hole-blocking selective contact to enable double-heterojunction crystalline silicon-based solar cell. Appl. Phys. Lett. 2015, 106, 123906. [CrossRef]

10. Kishimoto, H.; Takahama, K.; Hashimoto, N.; Aoi, Y.; Deki, S. Photocatalytic activity of titanium oxide prepared by liquid phase deposition (LPD). J. Mater. Chem. 1998, 8, 2019-2024. [CrossRef]

11. Lee, M.-K.; Lee, H.-C.; Hsu, C.-M. High dielectric constant $\mathrm{TiO}_{2}$ film grown on polysilicon by liquid phase deposition. Mater. Sci. Semicond. Process. 2007, 10, 61-67. [CrossRef]

12. Giebink, N.C.; Wiederrecht, G.P.; Wasielewski, M.R.; Forrest, S.R. Ideal diode equation for organic heterojunctions. I. Derivation and application. Phys. Rev. B 2010, 82, 155305. [CrossRef]

13. Fang, Q.; Meier, M.; Yu, J.J.; Wang, Z.M.; Zhang, J.Y.; Wu, J.X.; Kenyon, A.; Hoffmann, P.; Boyd, I.W. FTIR and XPS investigation of Er-doped $\mathrm{SiO}_{2}-\mathrm{TiO}_{2}$ films. Mater. Sci. Eng. B 2003, 105, 209-213. [CrossRef]

14. Xu, W.-X.; Zhu, S.; Fu, X.-C. XPS study of $\mathrm{TiO}_{\mathrm{x}}$ thin films deposited on glass substrates by the sol-gel process. Appl. Surf. Sci. 1998, 136, 194-205. [CrossRef]

15. Erdem, B.; Hunsicker, R.A.; Simmons, G.W.; Sudol, E.D.; Dimonie, V.L.; El-Aasser, M.S. XPS and FTIR Surface Characterization of $\mathrm{TiO}_{2}$ Particles Used in Polymer Encapsulation. Langmuir 2001, 17, 2664-2669. [CrossRef]

16. Pei, Z.; Hwang, H.L. Formation of silicon nano-dots in luminescent silicon nitride. Appl. Surf. Sci. 2003, 212-213, 760-764. [CrossRef]

17. Yu, P.; Tsai, C.-Y.; Chang, J.-K.; Lai, C.-C.; Chen, P.-H.; Lai, Y.-C.; Tsai, P.-T.; Li, M.-C.; Pan, H.-T.; Huang, Y.-Y.; et al. 13\% Efficiency Hybrid Organic/Silicon-Nanowire Heterojunction Solar Cell via Interface Engineering. ACS Nano 2013, 7, 10780-10787. [CrossRef]

18. Dingemans, G.; Kessels, W.M.M. Status and prospects of Al2O3-based surface passivation schemes for silicon solar cells. J. Vac. Sci. Technol. A 2012, 30, 040802. [CrossRef]

19. Schmidt, J.; Aberle, A.G. Accurate method for the determination of bulk minority-carrier lifetimes of monoand multicrystalline silicon wafers. J. Appl. Phys. 1997, 81, 6186-6199. [CrossRef]

20. Dao, V.A.; Heo, J.; Choi, H.; Kim, Y.; Park, S.; Jung, S.; Lakshminarayan, N.; Yi, J. Simulation and study of the influence of the buffer intrinsic layer, back-surface field, densities of interface defects, resistivity of p-type silicon substrate and transparent conductive oxide on heterojunction with intrinsic thin-layer (HIT) solar cell. Sol. Energy 2010, 84, 777-783. [CrossRef]

21. Pei, Z.; Thiyagu, S.; Jhong, M.-S.; Hsieh, W.-S.; Cheng, S.-J.; Ho, M.-W.; Chen, Y.-H.; Liu, J.-C.; Yeh, C.-M. An amorphous silicon random nanocone/polymer hybrid solar cell. Sol. Energy Mater. Sol. Cells 2011, 95, 2431-2436. [CrossRef]

22. Pei, Z.; Chang, S.; Liu, C.; Chen, Y. Numerical Simulation on the Photovoltaic Behavior of an Amorphous-Silicon Nanowire-Array Solar Cell. IEEE Electron. Device Lett. 2009, 30, 1305-1307.

23. Jeong, H.Y.; Lee, J.Y.; Choi, S.-Y.; Kim, J.W. Microscopic origin of bipolar resistive switching of nanoscale titanium oxide thin films. Appl. Phys. Lett. 2009, 95, 162108. [CrossRef] 